\title{
Shifts in national land use and food production in Great Britain after a climate tipping point
}

\author{
Paul D. L. Ritchie $\circledast^{1,2,9}$, Greg S. Smith $\oplus^{1,3,4,9}$, Katrina J. Davis $\oplus^{3}$, Carlo Fezzi, 3 , Solmaria Halleck-Vega ${ }^{6}$, \\ Anna B. Harper $\circledast^{1,7}$, Chris A. Boulton $\oplus^{1,2}$, Amy R. Binner $\circledast^{3}$, Brett H. Day33, Angela V. Gallego-Sala $\oplus^{2}$, \\ Jennifer V. Mecking $\oplus^{8}$, Stephen A. Sitch $\left(^{2}\right.$, Timothy M. Lenton ${ }^{1,2,9 \star}$ and lan J. Bateman $\left(^{1,3,9 \star}\right.$
}

Climate change is expected to impact agricultural land use. Steadily accumulating changes in temperature and water availability can alter the relative profitability of different farming activities and promote land-use changes. There is also potential for high-impact 'climate tipping points', where abrupt, nonlinear change in climate occurs, such as the potential collapse of the Atlantic Meridional Overturning Circulation (AMOC). Here, using data from Great Britain, we develop a methodology to analyse the impacts of a climate tipping point on land use and economic outcomes for agriculture. We show that economic and land-use impacts of such a tipping point are likely to include widespread cessation of arable farming with losses of agricultural output that are an order of magnitude larger than the impacts of climate change without an AMOC collapse. The agricultural effects of AMOC collapse could be ameliorated by technological adaptations such as widespread irrigation, but the amount of water required and the costs appear to be prohibitive in this instance.

ipping points can occur in elements of the climate system ${ }^{1}$ ecosystems ${ }^{2}$ and coupled social-ecological systems ${ }^{3}$, whereoften because of previous cumulative effects-a small change in drivers generates an abrupt response in a system, qualitatively changing its future state. The potential difficulties of reversing changes caused by tipping points ${ }^{4}$ mean there is a pressing need to understand their potential impacts and the extent to which such impacts can be ameliorated. However, economic assessments of the impacts of large-scale climate tipping points are rare ${ }^{4-6}$, typically of low resolution ${ }^{7}$ and often contested ${ }^{8,9}$.

To address these issues, we consider a well-studied tipping point; collapse of the Atlantic Meridional Overturning Circulation (AMOC) $)^{10,11}$. The AMOC includes surface ocean currents that transport heat from the tropics to the northeast Atlantic region, benefiting Western Europe, including the agricultural system of Great Britain. We contrast the impacts of conventional (hereafter, 'smooth') climate change with those of a climate tipping point involving AMOC collapse on agricultural land use and its economic value in Great Britain, with or without a technological response. Our climate projections span 2020-2080 and use a mid-range climate change scenario as a baseline (Fig. 1a-f; also see Methods, subsequent discussion of uncertainties such as weather variability, and sensitivity analysis in Extended Data Fig. 10; the results reported in the main text are mean effects). We take an existing simulation of the effects of AMOC collapse ${ }^{12,13}$ and treat it as a set of anomalies that can be linearly combined with the baseline (smooth) climate change scenario. We nominally assume that AMOC collapse occurs over the time period 2030-2050 (Fig. 1g-l; see Methods). This is a low-probability, fast and early collapse of the AMOC compared with current expectations ${ }^{14}$, emphasising the idealized nature of our study and our focus on assessing impacts. That said, the AMOC has recently weakened by $\sim 15 \%{ }^{15}$ and models may be biased to favour a stable AMOC relative to observations ${ }^{16}$.

We predict the production decisions of individual farms at $2 \mathrm{~km} \times 2 \mathrm{~km}$ grid resolution, building on an econometric landuse model ${ }^{17}$ and the detailed dataset ${ }^{18}$ employed by the Natural Environment Valuation model, which underpinned the UK National Ecosystem Assessment ${ }^{19}$. Smooth changes in climate (Fig. 1a-f) alter the relative profitability of agricultural products, generating changes in land use. For example, arable production is generally more profitable than grassland meat production in Great Britain (see Extended Data Fig. 1), but is limited by physical restrictions, such as topography or low temperatures. Climate change can raise temperatures, extending the area where cropping is economically viable provided that rainfall is sufficient ${ }^{18}$. Relative to 'smooth' climate change, a climate tipping point is likely to induce more abrupt land-use changes. For example, an AMOC collapse (Fig. 1g-1) is expected to induce significant reductions in rainfall ${ }^{20}$, which could rapidly shift land out of arable production ${ }^{21}$. A technological response to rainfall reductions in the agriculturally productive lowlands of the south and east might be to irrigate them. These climate and technological responses lead to four scenario combinations of land-use change under climate change: with or without AMOC collapse and with or without a technological (irrigation) response ${ }^{22}$.

\section{Land-use change under smooth climate change}

Figure 2a maps land use in 2020, as predicted by the agricultural model based on a spatially explicit analysis of physical environment, climate, economic and policy data from the 1960s to the present day, allowing for climate trends over that period. Here, physical

${ }^{1}$ Global Systems Institute, University of Exeter, Exeter, UK. ${ }^{2}$ College of Life and Environmental Sciences, University of Exeter, Exeter, UK. ${ }^{3}$ Land, Environment, Economics and Policy Institute, University of Exeter Business School, Exeter, UK. ${ }^{4}$ CSIRO Land and Water, Hobart, Tasmania, Australia. ${ }^{5}$ Department of Economics and Management, University of Trento, Trento, Italy. ${ }^{6}$ Wageningen University and Research, Wageningen, the Netherlands. ${ }^{7}$ College of Engineering, Mathematics and Physical Sciences, University of Exeter, Exeter, UK. ${ }^{8}$ Ocean and Earth Science, National Oceanography Centre Southampton, University of Southampton, Southampton, UK. ${ }^{9}$ These authors jointly supervised this work: Paul D. L. Ritchie, Greg S. Smith, Timothy M. Lenton, lan J. Bateman.

*e-mail:T.M.Lenton@exeter.ac.uk; I.Bateman@exeter.ac.uk 
Smooth climate change (AMOC continues)
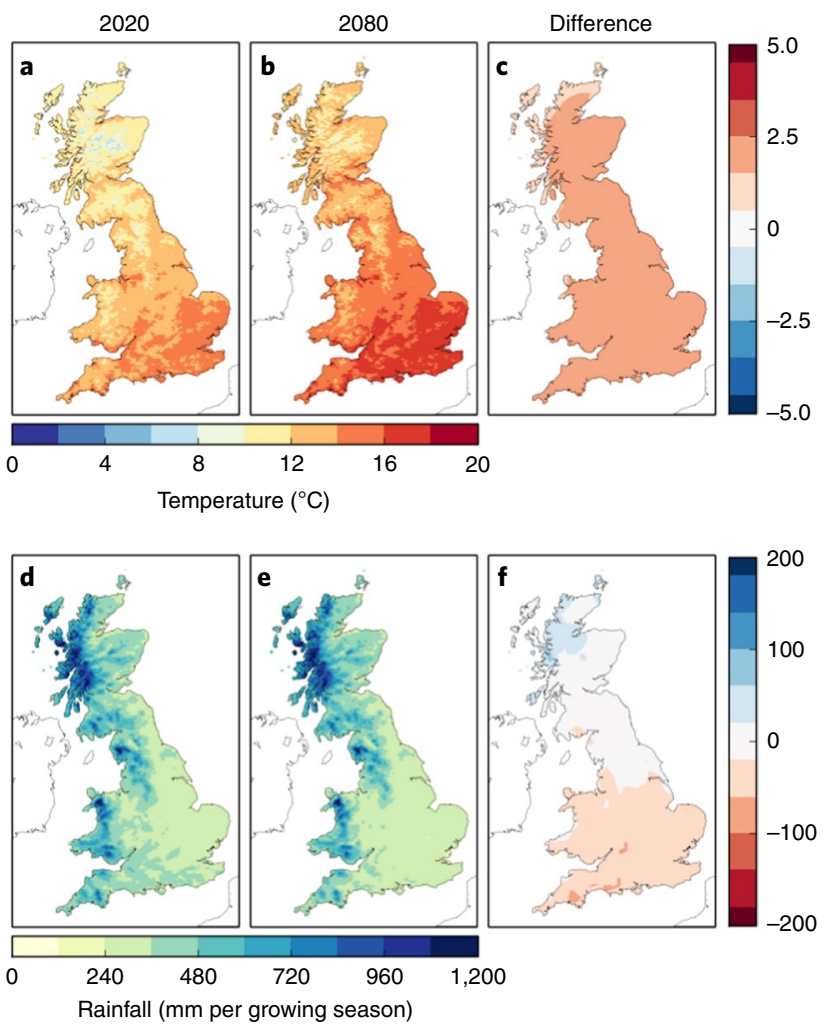

Abrupt climate change (AMOC collapse)

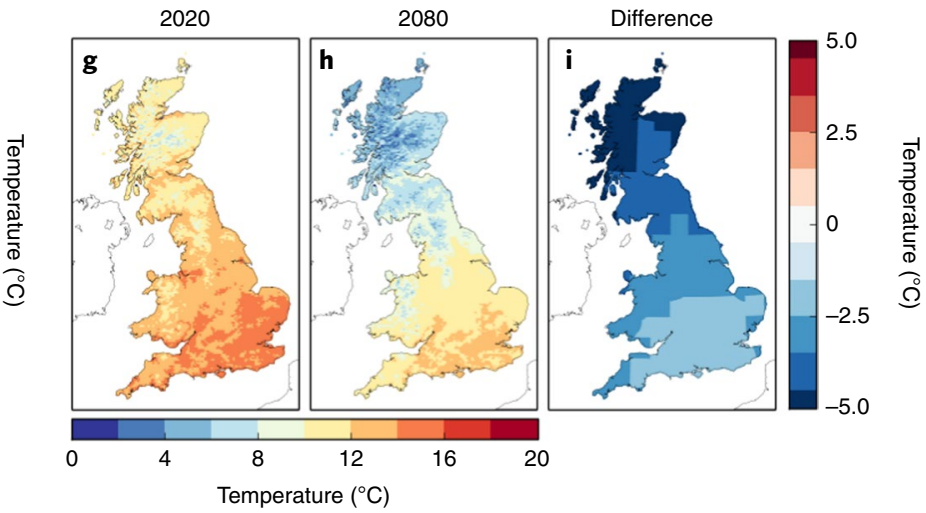

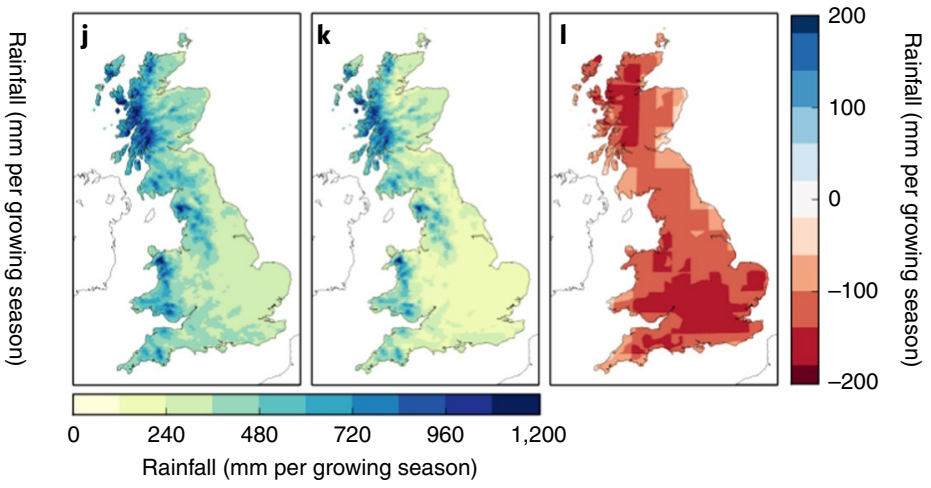

Fig. 1 | Temperature and rainfall for the growing season (April to September) in $\mathbf{2 0 2 0}$ and 2080. a-I, Temperature under smooth climate change (a-c), rainfall per growing season under smooth climate change (d-f), temperature under abrupt climate change ( $\mathbf{g}$-i) and rainfall per growing season under abrupt climate change (j-I) for the 2020 projection ( $\mathbf{a}, \mathbf{d}, \mathbf{g}$ and $\mathbf{j})$, the 2080 prediction ( $\mathbf{b}, \mathbf{e}, \mathbf{h}$ and $\mathbf{k}$ ) and the difference between the 2020 and 2080 climate variables (c, $\mathbf{f}, \mathbf{i}$ and $\mathbf{I}$ ). A positive (negative) value represents an increase (decrease) in 2080 compared with 2020.

constraints and cool temperatures are expected to constrain highvalue arable production-mainly to the lowlands of the south and east of Great Britain.

Our smooth climate change scenario results in a substantial $1.9^{\circ} \mathrm{C}$ mean warming in the growing season in 2080 relative to 2020 (from an average of $12.6^{\circ} \mathrm{C}$; Fig. 1a,c; see Methods), together with a modest $20-\mathrm{mm}$ mean decline in growing season rainfall (from an average of $445 \mathrm{~mm}$; Fig. 1d,f). Assuming that the AMOC is maintained, climate change is likely to induce a significant and profitable increase in the intensity of arable production across most lowland areas (Fig. 2b,c in contrast with Fig. 2a). These results indicate a modest increase in overall arable area, but in parts of eastern England, high temperatures and declining rainfall result in a reduction in arable production (Fig. 2b). Taking these differing effects into account, overall, British arable area rises from 32 to $36 \%$ of total agricultural area (see Extended Data Figs. 2 and 3), increasing agricultural output value by approximately $£ 40$ million per annum by 2080 (assuming 2017/18 agricultural prices). This value may increase further if, as best estimates suggest ${ }^{22,23}$, real (inflationadjusted) agricultural prices increase somewhat over the period as a result of climate change ${ }^{23-26}$ and other factors ${ }^{27,28}$.

Under smooth climate change, approximately $14 \%$ of Great Britain is likely to be rainfall limited by 2080 . If this proportion was irrigated from 2050, this would lead to an even greater rise in arable area-up from 32 to $42 \%$ of total agricultural land (Fig. 2 d,e and Extended Data Fig. 3). This generates an increase in agricultural production value of $£ 125$ million per annum by 2080 . The overall water requirements for such an intervention are relatively modest, with average demand across irrigated areas equivalent to approximately $18 \mathrm{~mm}$ of extra rainfall during the growing season. Nevertheless, recent estimates of the costs of irrigating British wheat production ${ }^{29}$ show that these costs exceed the value of additional production; in short, from an economic perspective, unless future arable crop prices rise sufficiently, such investment may not be worthwhile.

\section{Land-use change under a climate tipping point}

Our remaining scenarios impose a collapse of the AMOC over the period 2030-2050 overlaid on the smooth climate change trend. A previous study that combined a rapid AMOC collapse with future climate projections showed that temperatures will continue to rise globally, but with a delay of 15 years, while British temperatures will be dependent on the AMOC ${ }^{12,30-32}$. In the present study, the AMOC collapse reverses the warming seen in the smooth climate change scenarios, generating an average fall in temperature of $3.4^{\circ} \mathrm{C}$ by 2080 , accompanied by a substantial reduction in rainfall $(-123 \mathrm{~mm}$ during the growing season (Extended Data Figs. 2 and 4).

Holding real prices constant, in the absence of a technological response (that is, irrigation), rainfall (and to a lesser extent temperature) limitation due to AMOC collapse is predicted to affect arable farming in many areas (Fig. $2 \mathrm{f}, \mathrm{g}$ ). The expected overall area of arable production is predicted to fall dramatically from 32 to $7 \%$ of land area (Extended Data Figs. 2 and 3). This in turn generates a major reduction in the value of agricultural output, with a decrease of $£ 346$ million per annum (Table 1), representing a reduction in total income from British farming of $\sim 10 \%$ (ref. ${ }^{33}$ ). The key driver of the arable loss seen across Great Britain is climate drying due to AMOC collapse, rather than cooling (Fig. 3b,c). This adds 


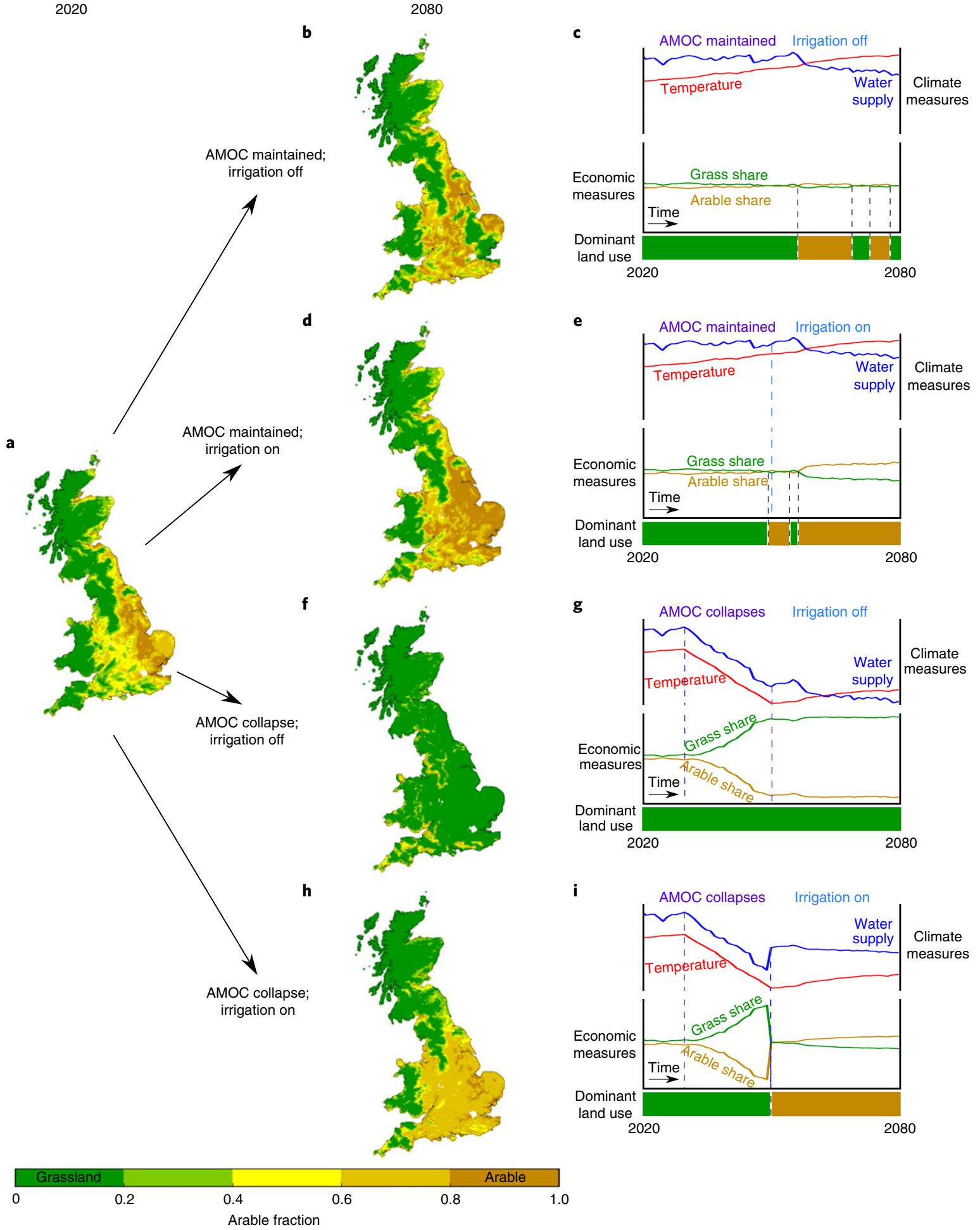

Fig. 2 | Impact of smooth and abrupt climate and economic change on the share of arable farmland in $\mathbf{2 0 2 0}$ and 2080. a, Arable farmland in 2020. $\mathbf{b}, \mathbf{d}, \mathbf{f}, \mathbf{h}$, Arable farmland in 2080 under maintained (b and $\mathbf{d})$ or collapsed AMOC scenarios (f and $\mathbf{h}$ ) with irrigation off (b and $\mathbf{f})$ or on (d and $\mathbf{h})$. c,e,g,i, Time series (England only) for mean climate and economic measures from 2020-2080 under the four scenarios considered (maintained (c and $\mathbf{e}$ ) or collapsed AMOC scenarios ( $\mathbf{g}$ and $\mathbf{I}$ ) with irrigation off ( $\mathbf{c}$ and $\mathbf{g}$ ) or on (e and $\mathbf{I})$ ). Water supply refers to the combination of rainfall and irrigation (if applicable).

considerably to the part of eastern England that is already vulnerable to arable loss due to drying under baseline climate change (green band in Figs. 2b and 3b). Part of eastern Scotland has a potential gain in arable production suppressed by the cooling effects of an AMOC collapse (contrast Figs. $2 \mathrm{f}$ and $3 \mathrm{c}$ ), but the loss of potential arable production due to cooling is small compared with the impacts of drying. However, the assumption of constant real prices is less plausible under the major global food system dislocation caused by a collapse of the AMOC. While firm estimates are not available, substantial food price increases are thought to be likely ${ }^{22,34}$. With the physical limits imposed by AMOC collapse constraining farm production, such price increases mean that wellbeing losses may be 


\begin{tabular}{|c|c|c|c|c|}
\hline & $\begin{array}{l}\text { Smooth climate change; } \\
\text { no technological change }\end{array}$ & $\begin{array}{l}\text { Smooth climate change } \\
\text { with technological change }\end{array}$ & $\begin{array}{l}\text { Abrupt climate change; } \\
\text { no technological change }\end{array}$ & $\begin{array}{l}\text { Abrupt climate change } \\
\text { with technological change }\end{array}$ \\
\hline AMOC & Maintained & Maintained & Collapse & Collapse \\
\hline Irrigation & No & Yes & No & Yes \\
\hline $\begin{array}{l}\text { Agricultural change value } \\
\text { (million pounds per annum) }\end{array}$ & 40 & 125 & -346 & 79 \\
\hline $\begin{array}{l}\text { Irrigation cost (million } \\
\text { pounds per annum) }\end{array}$ & 0 & -284 & 0 & -807 \\
\hline $\begin{array}{l}\text { Net value change (million } \\
\text { pounds per annum) }\end{array}$ & 40 & -159 & -346 & -728 \\
\hline
\end{tabular}

2020

a

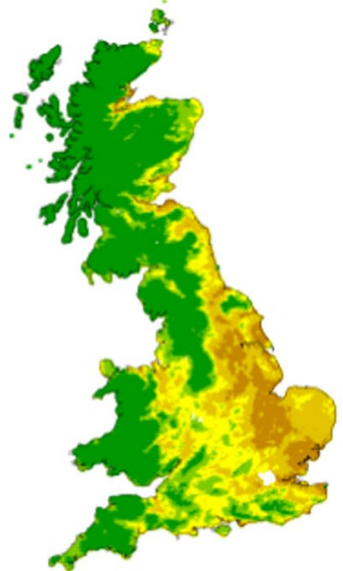

b

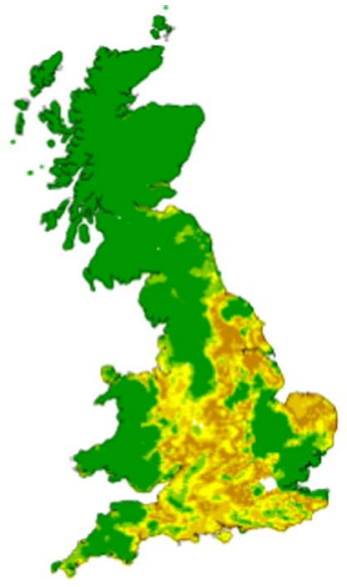

2080

c

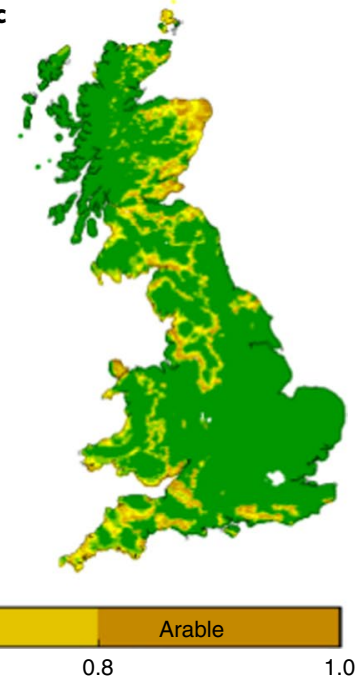

Fig. 3 | Limiting factors from an AMOC collapse on the share of arable land. a, Arable farmland for 2020. b, Arable farmland for 2080 , with temperature based on an AMOC collapse and rainfall under smooth climate change (no AMOC collapse). c, Arable farmland for 2080 , with rainfall based on an AMOC collapse and temperature under smooth climate change (no AMOC collapse).

significantly higher than those calculated here, implying that our results should be viewed as lower-bound, conservative estimates of the impacts of such a scenario.

With a change in technology to implement sufficient irrigation from 2050, the drying effects of the AMOC collapse on arable production could be substantially offset (Fig. 2h,i). In this scenario, land area under arable production still increases from 32 to $38 \%$ by 2080 , with an accompanying increase in output value of $£ 79$ million per annum (Table 1 and Extended Data Fig. 3). Nevertheless, these increases in extent and value are lower than under the second scenario where the AMOC is maintained, due to lower temperatures (contrast Fig. 2b with Fig. 2h). Furthermore, the more extreme reduction in rainfall caused by the AMOC collapse means that water required for adequate irrigation is much greater than under the scenario where the AMOC is maintained. Under the AMOC collapse scenario, $54 \%$ of British grid cells now require irrigation, with demand exceeding $150 \mathrm{~mm}$ in the growing season for some areas in the south and east of England (and an average demand across irrigated areas of $70 \mathrm{~mm}$ of extra rainfall) (Fig. 4). This would require water storage (across seasons) or spatial redistribution across the country from areas of higher rainfall in the north and western uplands of Great Britain. Irrigation costs incurred in this scenario are estimated at over $£ 800$ million per year-more than ten times the value of the arable production it would support (see Methods). So, again, irrigation costs outweigh amelioration benefits under climate change-a difference that is massively inflated by the climate tipping point of AMOC collapse. Our analysis also indicates the level of food cost increase (nearly three-quarters of a billion pounds) necessary to justify such irrigation expenditure costs.

\section{Future agriculture in Great Britain}

Table 1 summarizes the results from our analysis of the impacts of both smooth and abrupt climate change on agriculture in Great Britain. In the absence of a climate tipping point, smooth climate change results in an elevation of temperature with modest falls in water availability. Given the cool, moist present-day conditions of Great Britain, this results in a relatively small increase in agricultural net profits (smooth climate change; no technological change). A few areas (notably in eastern England) experience rainfall limitations, but the costs of irrigation outweigh the benefits of addressing these constraints (smooth climate change; with technological change). However, the introduction of a climate tipping point in the form of an AMOC collapse removes the possibility of any positive outcome for British agriculture. Reductions in temperature-and 


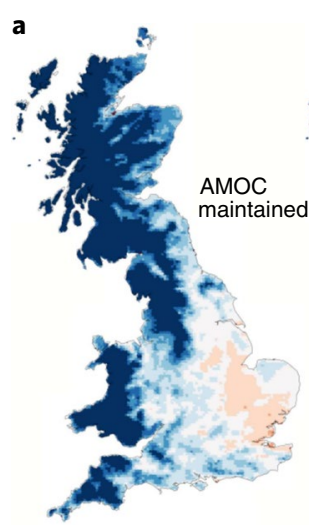

b

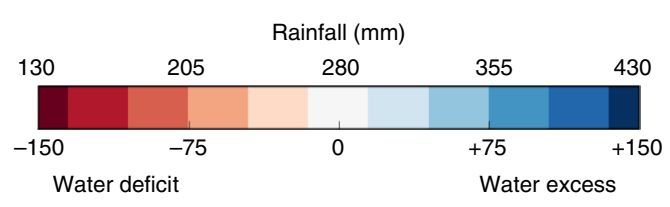

Fig. 4 | British water balance in 2080 during the growing season, with irrigation available, under the climate scenarios for which the AMOC is either maintained or collapsed. $\mathbf{a}, \mathbf{b}$, Water deficits $(<280 \mathrm{~mm})$ during the growing season (April to September) where irrigation occurs (red), and areas with excess water ( $>280 \mathrm{~mm}$ ) (blue), during the growing season when $A M O C$ is maintained (a) or collapsed (b).

especially rainfall-result in major losses in the value of agricultural production (abrupt climate change; no technological change). Although technological change in terms of widespread irrigation can ameliorate reductions in arable output (abrupt climate change; with technological change), in the absence of major price increases (which are plausible but uncertain), the costs of such investments dwarf the benefits they would provide.

Alongside economic uncertainties, agricultural land use, production and its value will also respond to a number of other variables, including changes in farming systems ${ }^{35}$, technology $y^{36,37}$ and national and international policy ${ }^{38,39}$. Even holding all of these factors constant, climate futures may themselves bring increased variability, including more frequent weather extremes, which may not be well reflected in mean temperature and rainfall trends ${ }^{26,40}$. A sensitivity analysis is therefore discussed in the Methods, with findings presented in Extended Data Fig. 10. This reveals substantial variability in the results; however, the key findings and relative comparisons across our four scenarios remain. There are a number of reasons for expecting such relativities to be robust. First, while there is uncertainty between models regarding the net effect of global warming and AMOC collapse on British temperatures, this is not the major control on arable fraction. Instead, predicted drying due to AMOC collapse is the key control, and this is robust across climate models (see Extended Data Fig. 5). The climate model we use is conservative in its predicted drying, but arable production is nevertheless still largely eliminated under AMOC collapse. Hence, using another climate model with greater predicted drying has relatively little scope to alter this key result. The major source of uncertainty in the economic analysis concerns future prices. Under smooth climate change, real prices are generally expected to increase, although only modestly. For example, the Intergovernmental Panel on Climate Change ${ }^{23}$ estimates a median increase of $7.6 \%$ (range: $1-23 \%$ ) in cereal prices by mid-century under smooth climate change. Previous analyses using the same agricultural landuse model show that such price increases, if sustained, could yield similar-scale effects to those induced by smooth climate change ${ }^{41}$. Given that potentially transformational improvements in food production technology ${ }^{28}$ and diets could dampen these effects, overall, this suggests that the estimates reported in the present paper, which assume constant real prices, should be seen as lower bound but of appropriate magnitude. There are several other expected impacts of AMOC collapse on Great Britain that are not considered. These include harsher winters, with greater storminess, and shortening of the growing season ${ }^{20,35}$. These would further tend to suppress arable production and challenge farming more generally. Weather variability is expected to increase under AMOC collapse and could lead to farmers diversifying their activity. Thus, while we already predict a nearly complete cessation of arable farming, the overall impact of AMOC collapse on farming activity and associated income could be considerably greater than we predict.

\section{Conclusion}

We have presented a detailed case study of the national impacts of a climate tipping point on land use, agricultural production and its economic value, together with an assessment of the potential for technological change to ameliorate impacts. While smooth climate change can result in major changes in land use and accompanying economic values, we show that passing a climate tipping point has the potential to generate order-of-magnitude greater economic impacts and that even these may be lower-bound estimates. Our case study concerns just one sector in one country, within which we only examine one impact of the substantial land-use changes predicted. While agricultural production is obviously important, changes in land use generate multiple impacts. The need to understand these changes, as well as their impacts on further sectors and countries, underlines the importance of many more such analyses.

\section{Methods}

Climate data. Observational temperature and rainfall data from 1981-2010 ${ }^{42}$ were used to estimate the land-use model on agricultural census data (June Agricultural Census panel from EDINA). Specifically, the surface observations, provided at $5 \mathrm{~km} \times 5 \mathrm{~km}$ resolution, were averaged over the growing seasons (April to September) and bilinearly interpolated (ignoring topography) onto the $2 \mathrm{~km} \times 2 \mathrm{~km}$ grid cell resolution used in the agricultural census.

The projected future climate data used in the agricultural model were supplied by the Met Office Hadley Centre Regional Model Perturbed Physics Ensemble simulations for the twenty-first century for the UK domain (HadRM3-PPE-UK) ${ }^{43}$ The runs consisted of daily data that span $1950-2100$ at $25 \mathrm{~km} \times 25 \mathrm{~km}$ resolution over the United Kingdom and form part of the UK Climate Projections, UKCP09 (ref. ${ }^{44}$ ). The ensemble is designed to simulate the regional climate over the United Kingdom for the historical and medium emissions scenario SRES-A1B ${ }^{45}$. In this paper, we chose the standard run, where parameters are kept at their unperturbed values, corresponding to a $3.5-\mathrm{K}$ global climate sensitivity, and again we bilinearly interpolated the data onto the $2 \mathrm{~km}$ grid used for the agricultural model. The climate projections used in the agricultural model for any given year consist of the mean temperature and rainfall for the growing seasons (April to September) of the preceding 30 years. To correct for any systematic bias in the modelled climate projections, the climate projections were bias corrected. The bias correction was performed by shifting the future projections by the mean bias between the modelled and observed data for 1960-1989 (the mean temperature and rainfall for 1960-1989 during the growing season is shown in Extended Data Fig. 6).

For simulation of an AMOC collapse, we used data from an experiment that used the HadGEM3 model with global configuration 2 (GC2), N216 atmospheric $(\sim 60 \mathrm{~km})$ and ORCA025 ocean $(\sim 25 \mathrm{~km})^{46}$. The coupled climate model simulations are a present-day control simulation and a simulation where the AMOC is collapsed using freshwater hosing, after which the model is allowed to run freely ${ }^{13,20}$. Both runs contain seasonal mean averages for a 30 -year period (again consistent with the time span used for estimation of the agricultural model) for temperature and rainfall once the model has reached a steady state. Specifically, the data period of 50-80 years after freshwater perturbations had ended was used for temperature and rainfall seasonal averages. Note that the results of Mecking et al. ${ }^{13}$ suggest that the reduction of rainfall over the North Atlantic following the collapse reduces with time; however, this effect is believed to be negligible at British latitudes. Extended Data Fig. 4 shows the temperature and rainfall for the spring and summer (effectively exchanging September for March in the growing season) for the maintained AMOC and collapsed AMOC scenarios.

Combining the difference between the HadGEM3 runs and the difference between the transient runs with the observation data, we were able to simulate an idealized AMOC collapse. This was consistent with findings from Drijfhout ${ }^{12}$, 
where a freshwater hosing run and a control run showed that the difference in surface air temperature after an AMOC collapse between the two runs remained approximately constant. A progressive (not instantaneous) collapse of the AMOC was simulated by applying a linear weighting function to the AMOC difference data during the prescribed years of AMOC weakening (namely 2030-2050). It should be noted that the speed of this collapse was relatively fast and the linearity assumption was idealized compared with what is predicted in some models.

The subsequent cooling and drying observed following an AMOC collapse is consistent among models (see Extended Data Fig. 5). Furthermore, the spatial pattern of greatest cooling in north west Great Britain and least cooling in south east Great Britain was prominent in an ensemble of freshwater hosing experiments in different climate models ${ }^{47}$.

Agricultural model. The agricultural land-use model builds on the data and econometric methodology developed by Fezzi and Bateman ${ }^{17}$, subsequently forming an essential component of the UK National Ecosystem Assessment (for example, Bateman et al. ${ }^{48}$ and the National Ecosystem Assessment ${ }^{19}$ ). This approach was also recently used by Fezzi and Bateman ${ }^{18}$ to appraise the environmental impact of climate change adaptation on land use and water quality. We used a simpler version of the model that focuses on understanding the determinants of agricultural land-use allocation between arable and grassland. While agricultural revenues change greatly with output prices, arable land is typically the highest-value agricultural activity in Great Britain (exceptions are some very intensive dairy farms located in the south west of the country), and therefore provides a proxy for understanding the effects of climate change on the $72 \%$ of UK land area under agricultural production ${ }^{33}$.

The land-use data were derived from the June Agricultural Census panel from EDINA (www.edina.ac.uk) and were collected on a $2 \mathrm{~km} \times 2 \mathrm{~km}$ grid $(400 \mathrm{Ha})$ basis covering the entirety of Great Britain for 11 unevenly spaced years from 1972-2010. This generates around 55,000 grid square records per year.

The model integrates germane environmental determinants of land use, including climate, soil characteristics and land gradient. Crop yield is not fixed but rather is allowed to depend on climate, soils, input levels and so on, and can therefore change across space and time. Crop productivity is therefore allowed to alter as climate changes and farmers are allowed to adapt by changing crop varieties, fertilization methods and so on. What we are not changing is the bundle of crop possibilities available to farmers. So, for example, no new genetically modified crops are brought into the analysis. The approach taken (not modelling yield directly, but focusing on land use via a discrete choice model) is the most established statistical land-use model approach, with contributions going back to $\mathrm{Wu}$ and Segerson ${ }^{47}$ and, more recently, Lubowski at al ${ }^{49}$, as well as our own exposition of the approach given in Fezzi and Bateman ${ }^{17}$. Recent research ${ }^{50}$ also shows that such an approach implies underlying and theoretically consistent profit and yield functions.

To account for nonlinear effects, rainfall and temperature in the growing season (April to September) were modelled using piecewise linear functions. This approach allowed us to capture changes in the proportion of land allocated to arable cropping resulting from different growth factors over a range of values (see refs. ${ }^{18,51}$ ). An interaction term was also included, to allow the effect of rainfall to depend on the effect of temperature and vice versa ${ }^{18,52}$. Soil characteristics included shares of peat $\left(s_{\text {peat }}\right)$, gravel $\left(s_{\text {gravel }}\right)$, stones $\left(s_{\text {stoney }}\right)$ or fragipan soil $\left(s_{\text {fragipan }}\right)$, as well as three dummy variables representing soil texture (namely, the share of fine, medium and coarse soils $\left(s_{\text {fine }}, s_{\text {medium }}\right.$ and $s_{\text {coarse }}$, respectively $\left.)\right)$. We used data from the Harmonized World Soil Database: a 30-arcsec (approximately 1-km resolution) raster (regular-gridded) database with over 16,000 different soil mapping units ${ }^{53}$. Finally, we included mean altitude (elev) and slope, represented as mean slope (slope), both derived from the 50-m-resolution Integrated Hydrological Digital Terrain Model licensed from the Centre for Ecology and Hydrology ${ }^{54}$.

To address potential spatial autocorrelation, the approach used by Fezzi and Bateman ${ }^{17}$ was followed, and every fourth cell along both the horizontal and vertical axis was sampled. We define grassland as the sum of rough grazing, permanent grassland and temporary grassland, and arable land as the sum of cereals, oilseed rape, root crops and all other agricultural lands. The only significant agricultural land-use category excluded from the agricultural model is rural woodland, whose expansion and contractions are mainly driven by governmental subsidies, which we assume remain constant across our climate change scenarios. As described on the source data website (www.edina.ac.uk), grid square land-use estimates can sometimes overestimate or underestimate the amount of agricultural land within an area, since their collection is based on the location of the main farm house. This feature is corrected by rescaling the sum of the different agricultural land-use areas assigned to each grid square to match with the total agricultural land derived using satellite land-cover data and ancillary spatial data ${ }^{55}$ (Meridian developed land-use areas, Ordnance Survey roads, Ordnance Survey railways and the National Inventory for Woodland and Trees), to locate areas that are used for agricultural production, urban activities and so on.

For policy determinants of land-use decisions, the share of each grid square designated as a national park (npark), environmentally sensitive area (esa) or greenbelt (greenbelt) is included. Environmentally sensitive areas, introduced in 1987 and extended in subsequent years, were launched to conserve and enhance areas of particular landscape and wildlife significance. Digital boundary data were downloaded from Natural England ${ }^{56}$ and the Scottish Government ${ }^{57}$. Spatial data for English greenbelts were licensed by the Department for Environment, Food and Rural Affairs from the Ordinance Survey ${ }^{55}$. Presently, there is no national digital spatial boundary dataset for Scottish greenbelts. Each council provided information and PDF maps or ESRI shapefiles. For Wales, there is currently only one area of greenbelt (Newport and Cardiff), and its boundaries were derived from local development plans.

The dependent variable of the model is the share of agricultural land devoted to arable. We model this variable as a function of all of the determinants of land use in a reduced-form specification. After applying a logit transformation, this model can be estimated via quasi-maximum likelihood ${ }^{58,59}$. The estimation results are reported in Extended Data Fig. 7. It can be observed that favourable environmental and topographical features (for example, soil quality and less elevated areas) significantly increase the share of arable. It is also apparent that policy factors are in line with expectations, in this case reducing the share of arable as these reflect a greater amount of protected areas: such as for national parks. Almost all of the parameter estimates of the rainfall and temperature effects are also highly statistically significant. These nonlinear impacts can also be observed in Extended Data Fig. 8.

Similarly, it emerges from Extended Data Fig. 8 that warmer temperatures are beneficial for arable, as this promotes plant growth with the trend increasing quite rapidly at first, and then more gradually. In the full sample, higher temperature extremes can have adverse impacts, but this is based on a small number of observations with average growing season temperatures above $14^{\circ} \mathrm{C}$. For this reason, a subsample was taken, as the nonlinear climate effects are sensitive to the inclusion of these few observations. The estimates of all other variables are very similar, regardless of basing the estimations on the full sample or subsample. A simple quadratic specification showed increases in predicted arable share with increasing temperature; this provided further evidence of the robustness of the study's results to the model specification.

It is also evident that higher accumulated rainfall over the growing season negatively affects arable share (for example, from flooding or waterlogging) (Extended Data Fig. 8). When all observations are used, the estimates also corroborate a downward trend of arable with respect to average rainfall of $<300 \mathrm{~mm}$, but few observations exist below $290 \mathrm{~mm}$. The few observations with lower rainfall levels are also those with observed higher average temperatures. However, under the smooth and abrupt (AMOC collapse) climate change scenarios we consider in this study, there is a growing shift towards less rainfall in the summer and therefore the functional form requires extending below $290 \mathrm{~mm}$. We applied a conservative approach by applying a linear extrapolation to the downward trend (Extended Data Fig. 8). Using land-cover data from the European Space Agency Climate Change Initiative ${ }^{60}$ and average growing season rainfall values from 1988-2017 (CRU TS4.02; ref. ${ }^{61}$ ), we have provided arable share for rainfall values that go outside the range of British data. We used Land Cover CCI tools (version 3.14) to re-grid the land-cover data from the original $300 \mathrm{~m}$ spatial resolution to the half-degree resolution of the Climatic Research Unit data. Two regions were selected based on comparable agricultural extent and climate to Great Britain: the US Great Plains $\left(87^{\circ} \mathrm{W}\right.$ to $113^{\circ} \mathrm{W} ; 35^{\circ} \mathrm{N}$ to $\left.49^{\circ} \mathrm{N}\right)$ and an area covering northern Eurasia $\left(10^{\circ} \mathrm{W}\right.$ to $50^{\circ} \mathrm{E} ; 43^{\circ} \mathrm{N}$ to $\left.60^{\circ} \mathrm{N}\right)$. We also included data from over the United Kingdom, which showed a similar increasing trend in arable share with lower rainfall values (above $300 \mathrm{~mm}$ ). We define arable as rain-fed crops, including land with herbaceous, tree or shrub cover, while pasture is defined as mosaic herbaceous and grassland. The turning point estimated for Great Britain is similar to that observed for the US Great Plains and a little lower for Eurasia (the latter might reflect differences in the crop types used). In both cases, the fall in arable share for rainfall below the turning point is sharper than our estimation, suggesting that we applied a conservative approach. In addition to complex rainfall patterns being more difficult to predict, there is also the issue of predicting how evenly distributed the rainfall is over the growing season. This would be interesting to explore in another study, as well as crop variations.

Our agricultural model does not explicitly account for the introduction of technological advances in the form of new crops, which could also help to attenuate the negative impacts of the AMOC collapse. Effects other than temperature and rainfall (in particular $\mathrm{CO}_{2}$ fertilization) are not accounted for, and $\mathrm{CO}_{2}$ fertilization has the potential to increase the water-use efficiency of $\mathrm{C}_{3}$ crop plants and thus reduce the corresponding irrigation demand ${ }^{62}$. Any agricultural model should be sensitive to prices and subsidies, and ours is no exception. Arable farm profit margins are typically higher than for beef and sheep livestocking. While dairy farms currently enjoy high per-hectare margins (see the statistics reported by Fezzi et al. ${ }^{63}$ ), the capital costs of moving into such production are prohibitive for most livestock farms, and many small dairy farms are uneconomic ${ }^{64}$.

Economic analysis. Estimates of changes in farm profitability for the four scenarios were calculated using country estimates of arable and grassland profitability. Profitability figures were taken from the Farm Business Survey ${ }^{6}$ for England and Wales and the Farm Business Income survey for Scotland ${ }^{57}$. 
Arable profitability was calculated as the average profitability per hectare from cereal and general-cropping farming for a medium-sized farm. Grassland profitability is dependent on whether the land is classified as being in less favoured areas (LFAs). LFAs were introduced by the European Union to support farming where production conditions are difficult, and are defined according to the different physical and socioeconomic characteristics across the regions. LFAs are available for England (https://magic.defra.gov.uk/Dataset_Download_Summary. htm) and Scotland (https://data.gov.uk/dataset/a1ba43dd-569c-47e9-962321664aaf49ff/less-favoured-areas). For Wales, we estimated LFAs by taking the lowland areas classified in LandMap (http://lle.gov.wales/catalogue/item/Land mapVisualSensory/?lang=en). Extended Data Fig. 1 shows the changes in farm profitability for farms in England, Scotland and Wales under the four scenarios. Agricultural prices and irrigation costs were fixed throughout the economic analyses, assuming 2017/18 prices.

In principle, the irrigation water demands considered in our analyses could be met by either storage of water during the wetter, non-growing season, or spatial redistribution from those areas of Great Britain with surplus rainfall. Irrigation costs were estimated using values from a recent study on the costs of irrigating wheat production in the East of England ${ }^{36}$, which estimated total system costs for irrigation at $£ 163.60$ per hectare. Under the scenario with smooth climate and technological change, areas in Great Britain with insufficient rainfall for arable production (14\% of British grid cells) require, on average, an additional $18 \mathrm{~mm}$ of rainfall in the growing season. Under a scenario with abrupt climate and technological change, areas in Great Britain that require irrigation (54\% of grid cells) require an additional $70 \mathrm{~mm}$ in the growing season. To meet this latter shortfall, water could be redistributed across the country from areas that do not require irrigation-there is an average excess (after use) of $167 \mathrm{~mm}$ of rainfall in the growing season in these areas. This equates to a positive difference of $39 \mathrm{~mm}$ across Great Britain. In other words, there is sufficient rainfall within Great Britain to meet all irrigation needs. However, as discussed in the main text, the costs of these technological interventions dwarf the benefits they would provide (Table 1 ).

Sensitivity analysis. We performed a sensitivity analysis to assess the impact of the climate variables (temperature and rainfall) on arable share. Extended Data Fig. 2 provides the lower and upper quartiles of the temperature and rainfall for selected years over the previous 30 years (as used in the agricultural model). Using the different combinations of the lower and upper quartiles of temperature and rainfall, together with the means used in the original analysis, we generated eight additional arable fraction values. The ranges of these outputs are displayed in Extended Data Figs. 2 and 9 for the different scenarios.

The ranges of arable fractions suggest that the ranking of the scenarios is consistent with the ranking obtained using the means. The worst scenario for the arable fraction remains the abrupt climate with no technological change, which drops from a range of $19-34 \%$ in 2020 to $3-16 \%$ by 2080 . The best scenario remains the smooth climate with technological change, which increases from $19-34 \%$ in 2020 to $28-52 \%$ by 2080 . The results show that climate projection variance is important in determining land-use outputs. The arable fraction ranges presented in Extended Data Fig. 2 are wide, reflecting the uncertainty in the climate projections. This uncertainty also translates into uncertainty in the economic analysis. The economic value ranges from the sensitivity analysis are displayed in Extended Data Fig. 10 for the different scenarios. Despite the wide ranges around the economic values, the patterns are still consistent with those reported in the main text. Abrupt climate change generates a major reduction in the value of agricultural output, falling by $£ 218-393$ million per annum, representing a substantial reduction in total income from British farming. The cost ranges of irrigation become very wide as the upper quartile for rainfall results in lower demand for irrigation while the lower quartile results in higher demand, leading to wider uncertainty about the costs of the two scenarios involving technological change.

\section{Data availability}

The modelled output data that support the findings of this study are openly available from Smith and Ritchie ${ }^{66}$.

Received: 15 May 2019; Accepted: 22 November 2019; Published online: 13 January 2020

\section{References}

1. Lenton, T. M. et al. Tipping elements in the Earth's climate system. Proc. Natl Acad. Sci. USA 105, 1786-1793 (2008).

2. Scheffer, M., Carpenter, S., Foley, J. A., Folke, C. \& Walker, B. Catastrophic shifts in ecosystems. Nature 413, 591-596 (2001).

3. Milkoreit, M. et al. Defining tipping points for social-ecological systems scholarship - an interdisciplinary literature review. Environ. Res. Lett. 13, 033005 (2018)

4. Lenton, T. M. \& Ciscar, J.-C. Integrating tipping points into climate impact assessments. Clim. Change 117, 585-597 (2013).
5. Kopp, R. E., Shwom, R. L., Wagner, G. \& Yuan, J. Tipping elements and climate-economic shocks: pathways toward integrated assessment. Earth's Future 4, 346-372 (2016).

6. Vaughan, D. G. \& Spouge, J. R. Risk estimation of collapse of the West Antarctic Ice Sheet. Clim. Change 52, 65-91 (2002).

7. Boulton, C. A., Allison, L. C. \& Lenton, T. M. Early warning signals of Atlantic Meridional Overturning Circulation collapse in a fully coupled climate model. Nat. Commun. 5, 5752 (2014).

8. Link, P. M. \& Tol, R. S. Estimation of the economic impact of temperature changes induced by a shutdown of the thermohaline circulation: an application of FUND. Clim. Change 104, 287-304 (2011).

9. Tol, R. S. The economic effects of climate change. J. Econ. Pers. 23, 29-51 (2009).

10. Hofmann, M. \& Rahmstorf, S. On the stability of the Atlantic Meridional Overturning Circulation. Proc. Natl Acad. Sci. USA 106, 20584-20589 (2009).

11. Rahmstorf, S. et al. Exceptional twentieth-century slowdown in Atlantic Ocean overturning circulation. Nat. Clim. Change 5, 475-480 (2015).

12. Drijfhout, S. Competition between global warming and an abrupt collapse of the AMOC in Earth's energy imbalance. Sci. Rep. 5, 14877 (2015).

13. Mecking, J., Drijfhout, S., Jackson, L. \& Graham, T. Stable AMOC off state in an eddy-permitting coupled climate model. Clim. Dynam. 47, 2455-2470 (2016).

14. IPCC Climate Change 2013: The Physical Science Basis (eds Stocker, T. F. et al.) (Cambridge Univ. Press, 2013).

15. Caesar, L., Rahmstorf, S., Robinson, A., Feulner, G. \& Saba, V. Observed fingerprint of a weakening Atlantic Ocean overturning circulation. Nature 556, 191-196 (2018)

16. Liu, W., Xie, S.-P., Liu, Z. \& Zhu, J. Overlooked possibility of a collapsed Atlantic Meridional Overturning Circulation in warming climate. Sci. Adv. 3 e1601666 (2017).

17. Fezzi, C. \& Bateman, I. J. Structural agricultural land use modeling for spatial agro-environmental policy analysis. Am. J. Agric. Econ. 93, 1168-1188 (2011).

18. Fezzi, C. \& Bateman, I. The impact of climate change on agriculture: nonlinear effects and aggregation bias in Ricardian models of farmland values. J. Assoc. Environ. Res. Econ. 2, 57-92 (2015).

19. UK National Ecosystem Assessment: Technical Report (United Nations Environmental Programme World Conservation Monitoring Centre, 2011).

20. Jackson, L. et al. Global and European climate impacts of a slowdown of the AMOC in a high resolution GCM. Clim. Dynam. 45, 3299-3316 (2015).

21. Cook, B. I., Ault, T. R. \& Smerdon, J. E. Unprecedented 21st century drought risk in the American Southwest and Central Plains. Sci. Adv. 1, e1400082 (2015).

22. Benton, T. et al. Environmental Tipping Points and Food System Dynamics: Main Report (The Global Food Security Programme, 2017).

23. IPCC. Special Report on Climate Change and Land (IPCC, 2019).

24. Porter, J. R. et al. in Climate Change 2014: Impacts, Adaptation, and Vulnerability (eds Field, C. B. et al.) 485-533 (Cambridge Univ. Press, 2014).

25. Mbow, C. et al. in Special Report on Climate Change and Land Ch 5 (IPCC, 2019).

26. Extreme Weather and Resilience of the Global Food System (Global Food Security Programme, 2015).

27. Shaping the Future of Global Food Systems: A Scenarios Analysis (World Economic Forum, 2017).

28. Global Strategic Trends: The Future Starts Today. 6th edn (Ministry of Defence, 2018).

29. El Chami, D., Knox, J., Daccache, A. \& Weatherhead, E. The economics of irrigating wheat in a humid climate-a study in the East of England. Agric. Syst. 133, 97-108 (2015)

30. Swingedouw, D. et al. Impact of freshwater release in the North Atlantic under different climate conditions in an OAGCM. J. Clim. 22, 6377-6403 (2009)

31. Vellinga, M. \& Wood, R. A. Global climatic impacts of a collapse of the Atlantic Thermohaline Circulation. Clim. Change 54, 251-267 (2002).

32. Jacob, D. et al. Slowdown of the thermohaline circulation causes enhanced maritime climate influence and snow cover over Europe. Geophys. Res. Lett. 32, L21711 (2005).

33. National Statistics. Agriculture in the United Kingdom 2017 (Department for Environment, Food and Rural Affairs, Department of Agriculture, Environment and Rural Affairs (Northern Ireland), Welsh Assembly Government Department for Rural Affairs and Heritage \& Scottish Government Rural and Environment Science and Analytical Services, 2018).

34. Nordhaus, W. \& Boyer, J. Warming the World: Economic Models of Global Warming (MIT Press, 2000).

35. Brayshaw, D. J., Woollings, T. \& Vellinga, M. Tropical and extratropical responses of the North Atlantic atmospheric circulation to a sustained weakening of the MOC. J. Clim. 22, 3146-3155 (2009).

36. Dinesh, D., Campbell, B., Bonilla-Findji, O. \& Richards, M. 10 Best Bet Innovations for Adaptation in Agriculture: A Supplement to the UNFCCC NAP Technical Guidelines. CCAFS Working Paper No. 215 (CGIAR Research Program on Climate Change, Agriculture and Food Security, 2017). 
37. Madramootoo, C. Emerging Technologies for Promoting Food Security: Overcoming the World Food Crisis (Woodhead Publishing, 2015).

38. Benton, T. G., Froggatt, A., Wright, G., Thompson, C. E. \& King, R. Food Politics and Policies in Post-Brexit Britain (Chatham House, 2019).

39. Challinor, A. J. et al. Transmission of climate risks across sectors and borders. Phil. Trans. R. Soc. A Math. Phys. Eng. Sci. 376, 20170301 (2018).

40. Benton, T. G., Gallani, B., Jones, C., Lewis, K. \& Tiffin, R. Severe Weather and UK Food Chain Resilience (Government Office for Science, 2012).

41. Fezzi, C. et al. Valuing provisioning ecosystem services in agriculture: the impact of climate change on food production in the United Kingdom. Environ. Res. Econ. 57, 197-214 (2014)

42. Met Office. UKCP09: Met Office Gridded Land Surface Climate ObservationsLong Term Averages at $5 \mathrm{~km}$ Resolution (Centre for Environmental Data Analysis, 2017).

43. Hadley Centre for Climate Prediction and Research. UKCP09: Met Office HadRM3-PPE UK Model Runs (NCAS British Atmospheric Data Centre, 2014).

44. Jenkins, G. UK Climate Projections: Briefing Report (Met Office Hadley Centre, 2009).

45. Nakicenovic, N. et al. Special Report on Emissions Scenarios (SRES), a Special Report of Working Group III of the Intergovernmental Panel on Climate Change (Cambridge Univ. Press, 2000).

46. Safta, C. et al. Global sensitivity analysis, probabilistic calibration, and predictive assessment for the data assimilation linked ecosystem carbon model. Geosci. Model Dev. 8, 1899-1918 (2015).

47. Wu, J. \& Segerson, K. The impact of policies and land characteristics on potential groundwater pollution in Wisconsin. Am. J. Agric. Econ. 77, 1033-1047 (1995)

48. Bateman, I. J. et al. Bringing ecosystem services into economic decision-making: land use in the United Kingdom. Science 341, 45-50 (2013).

49. Lubowski, R. N., Plantinga, A. J. \& Stavins, R. N. Land-use change and carbon sinks: econometric estimation of the carbon sequestration supply function. J. Environ. Econ. Manage. 51, 135-152 (2006).

50. Carpentier, A. \& Letort, E. Multicrop production models with multinomial logit acreage shares. Environ. Res. Econ. 59, 537-559 (2014).

51. Schlenker, W. \& Roberts, M. J. Nonlinear temperature effects indicate severe damages to US crop yields under climate change. Proc. Natl Acad. Sci. USA 106, 15594-15598 (2009).

52. Morison, J. \& Morecroft, M. Plant Growth and Climate Change (Blackwell Publishing, 2006).

53. Van Liedekerke, M., Jones, A. \& Panagos, P. ESDBv2 Raster Library-A Set of Rasters Derived from the European Soil Database Distribution v2.0. (European Commission \& European Soil Bureau Network, 2006).

54. Integrated Hydrological Digital Terrain Model (Centre for Ecology and Hydrology, 2002).

55. Meridian 2 Developed Land Use Area (Ordinance Survey, 2013).

56. Digital Map Boundaries. Natural England Open Data Geoportal https:// naturalengland-defra.opendata.arcgis.com/ (Natural England, 2012).

57. Digital Map Boundaries. Scottish Government Spatial Data https://www. spatialdata.gov.scot/ (Scottish Government, 2012)
58. Papke, L. E. \& Wooldridge, J. M. Econometric methods for fractional response variables with an application to $401(\mathrm{k})$ plan participation rates. J. Appl. Econ. 11, 619-632 (1996).

59. Papke, L. E. \& Wooldridge, J. M. Panel data methods for fractional response variables with an application to test pass rates. J. Econ. 145, 121-133 (2008).

60. Climate Change Initiative, Version 2.0 (European Space Agency, 2017); http://cci.esa.int/

61. Harris, I., Jones, P. D., Osborn, T. J. \& Lister, D. H. Updated high-resolution grids of monthly climatic observations-the CRU TS3.10 Dataset. Int. J. Climatol. 34, 623-642 (2014).

62. Long, S. P., Ainsworth, E. A., Leakey, A. D. B., Nösberger, J. \& Ort, D. R. Food for thought: lower-than-expected crop yield stimulation with rising $\mathrm{CO}_{2}$ concentrations. Science 312, 1918-1921 (2006).

63. Fezzi, C., Rigby, D., Bateman, I. J., Hadley, D. \& Posen, P. Estimating the range of economic impacts on farms of nutrient leaching reduction policies. Agric. Econ. 39, 197-205 (2008).

64. MacDonald, J. M. et al. Profits, Costs, and the Changing Structure of Dairy Farming (Economic Research Service \& USDA, 2007).

65. Farm Business Survey (Department for Environment, Food and Rural Affairs, 2018).

66. Smith, G. S. \& Ritchie, P. D. L. Modelled Arable Area for Great Britain Under Different Climate and Policy Scenarios (NERC Environmental Information Data Centre, 2019).

\section{Acknowledgements}

This work was supported by the NERC Valuing Nature programme (NE/P007880/1). We are grateful for comments from T. Benton.

\section{Author contributions}

I.J.B. and T.M.L. designed and directed the research. P.D.L.R. and G.S.S. helped to shape the research. P.D.L.R., G.S.S., K.J.D., I.J.B. and T.M.L. wrote the manuscript. C.F., C.A.B., A.B.H., A.V.G.-S., J.V.M., S.H.-V. and S.A.S. provided support and revisions. P.D.L.R., G.S.S. and K.J.D. planned and conducted simulations for all analyses. C.F. designed and ran the original agriculture land-use model with support from A.R.B., B.H.D. and I.J.B. C.F. and S.H.-V. further developed the agricultural land-use model from a global analysis of agricultural land use designed by A.B.H. and A.V.G.-S. The climate data were sourced and corrected for modelled bias by P.D.L.R. J.V.M. designed and ran the AMOC climate simulations.

\section{Competing interests}

The authors declare no competing interests.

\section{Additional information}

Extended data is available for this paper at https://doi.org/10.1038/s43016-019-0011-3.

Correspondence and requests for materials should be addressed to T.M.L. or I.J.B.

Reprints and permissions information is available at www.nature.com/reprints.

Publisher's note Springer Nature remains neutral with regard to jurisdictional claims in published maps and institutional affiliations.

(C) The Author(s), under exclusive licence to Springer Nature Limited 2020 
Panel a: Changes in farm profitability for England, Scotland and Wales

England Change in Agricultural profit 2020 to 2060 (£ Million)

$+47$

$+82$

$-313$

$+61$
Change in Agricultural profit 2020 to 2080 ( $£$ Million)

$+29$

$+114$

$-315$

$+90$

\section{Scotland}

\begin{tabular}{|c|c|c|}
\hline Smooth climate, no technological change & -10 & +3 \\
\hline Smooth climate with technological change & -10 & +3 \\
\hline Abrupt climate, no technological change & -40 & -35 \\
\hline Abrupt climate, with technological change & -35 & -26 \\
\hline \multicolumn{3}{|l|}{ Wales } \\
\hline Smooth climate, no technological change & +6 & +8 \\
\hline Smooth climate with technological change & +6 & +8 \\
\hline Abrupt climate, no technological change & -1 & +4 \\
\hline Abrupt climate, with technological change & +9 & +15 \\
\hline \multicolumn{3}{|l|}{ Total } \\
\hline Smooth climate, no technological change & +43 & +40 \\
\hline Smooth climate with technological change & +78 & +125 \\
\hline Abrupt climate, no technological change & -354 & -346 \\
\hline Abrupt climate, with technological change & +35 & +79 \\
\hline \multicolumn{3}{|c|}{ Panel b: Estimates of average Farm Profitability for England, Scotland and Wales } \\
\hline $\begin{array}{c}\text { Arable } \\
(£ \text { per } \mathrm{Ha})\end{array}$ & $\begin{array}{c}\text { Lowland grassland (Lowland Grazing } \\
\text { Livestock) } \\
\text { (f per Ha) }\end{array}$ & $\begin{array}{c}\text { Upland grassland (Less Favoured Areas } \\
\text { Grazing Livestock) } \\
\text { (£ per Ha) }\end{array}$ \\
\hline England $^{a}$ & 262.30 & 222.50 \\
\hline Scotland $^{\mathrm{b}}$ & 141.50 & 82.60 \\
\hline Wales $^{\mathrm{a}}$ & 306.50 & 225.50 \\
\hline \multicolumn{3}{|c|}{$\begin{array}{l}\text { Notes: a England and Wales farm profitability is reported as the net profits from the Farm Business Survey (FBS) } 2017 / 2018^{65} .{ }^{b} S^{2}+t t i \\
\text { farm profitability is calculated from the Scottish farm business income (FBI): annual estimates } 2016-2017^{57} \text {. }{ }^{\text {Farm }} \text { Business Survey } \\
\text { values are not available for arable profit in Wales, for which values from England are used. Note that this comparison excludes dairy } \\
\text { production as this tends to be limited by the availability of high levels of capital input which in turn is heavily influenced by historic } \\
\text { access to milk quota subsidies that have now been abandoned. }\end{array}$} \\
\hline
\end{tabular}

Extended Data Fig. 1 | Changes in farm profitability between 2020 and 2060 and between 2020 and 2080. Changes in farm profitability between 2020 and 2060 and between 2020 and 2080 
Panel a: Mean temperature and rainfall for previous 30-year growing seasons (April-September) when the Atlantic meridional overturning circulation (AMOC) is maintained or collapses.

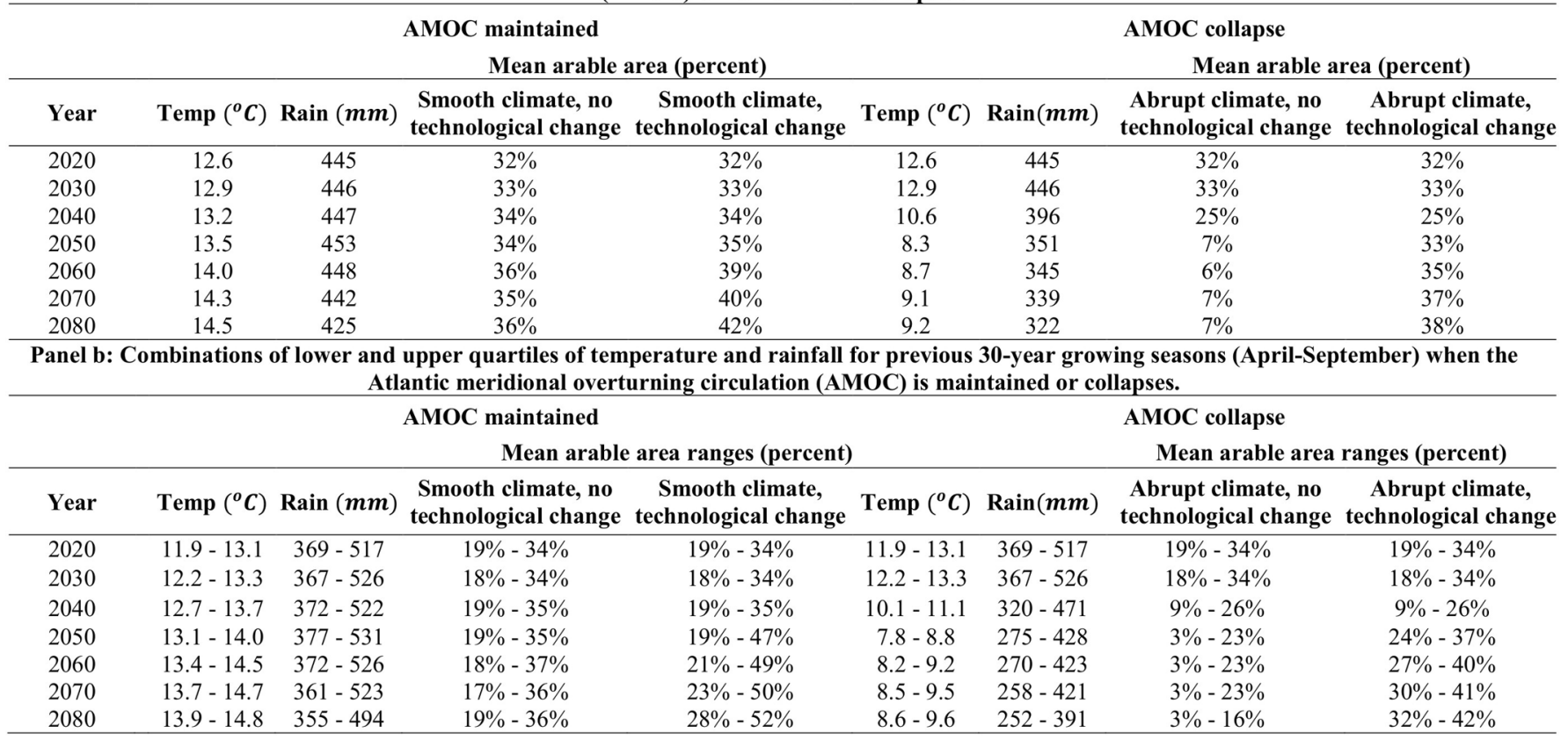

Extended Data Fig. 2 | Predicted farm allocation to arable land for individual years between $\mathbf{2 0 2 0}$ and $\mathbf{2 0 8 0}$ per $\mathbf{2}$ km grid cell. Predicted farm allocation to arable land for individual years between 2020 and 2080 per $2 \mathrm{~km}$ grid cell 

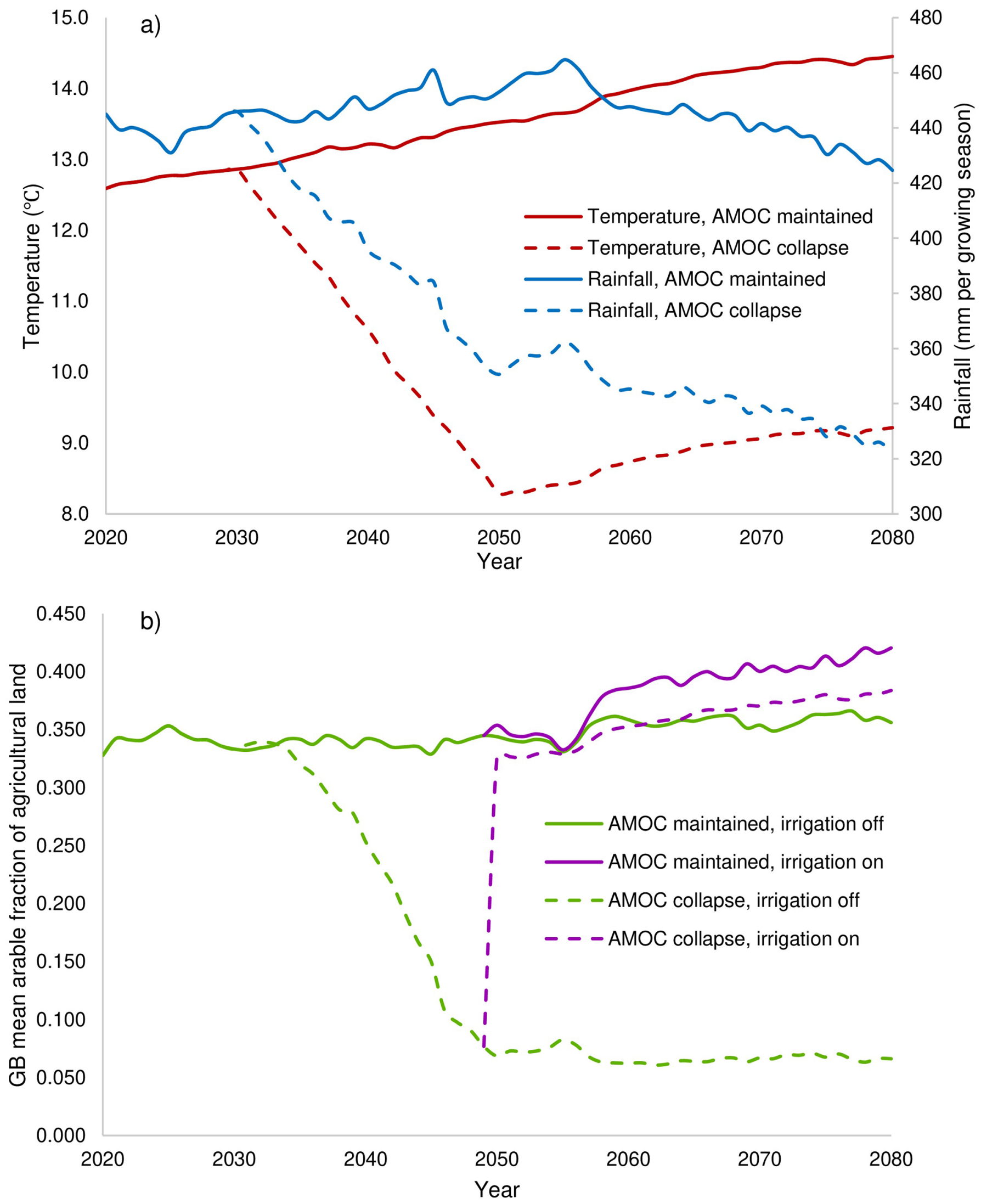

Extended Data Fig. 3 | Time series of mean temperature, total rainfall for the growing season and arable share for the four scenarios considered. a) Temperature and rainfall in Great Britain with AMOC maintained and collapsed over 2020 to 2080. b) Mean arable fraction of agricultural land in Great Britain with AMOC maintained or collapsed and irrigation on or off, over the period 2020 to 2080 


\section{AMOC maintained \\ AMOC collapsed \\ Difference}
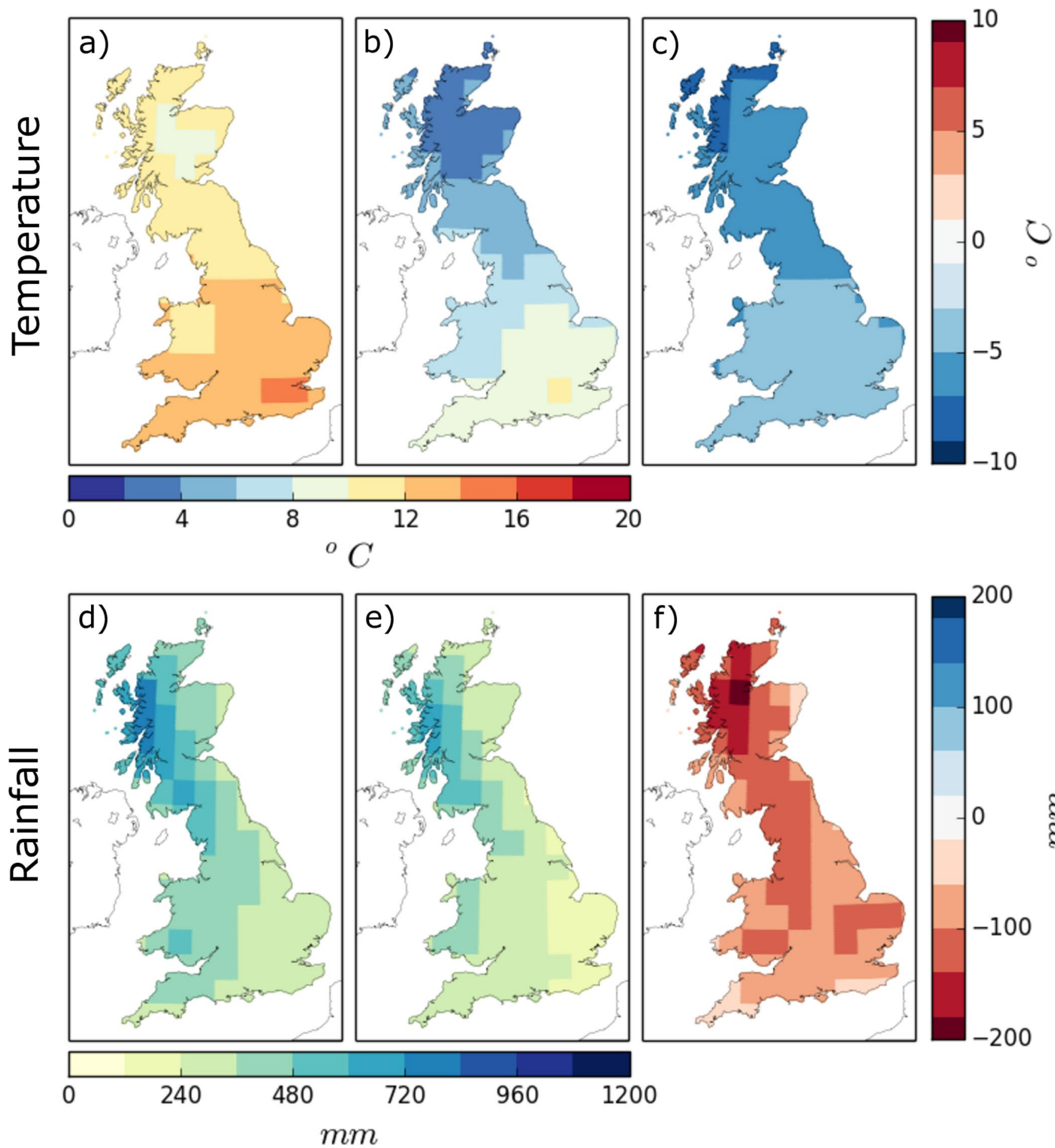

Extended Data Fig. 4 | Mean temperature and total rainfall for spring and summer (March-August) in steady state runs of the AMOC maintained and collapsed. a) - c) Mean temperature and d) - f) mean total rainfall for a), d) a maintained AMOC and b), e) collapsed AMOC ${ }^{13,20}$. c), f) Plots the difference between the means of the AMOC maintained and collapsed; a positive (negative) value represents an increase (decrease) for an AMOC collapse compared to the AMOC maintained 


\begin{tabular}{|c|c|c|c|c|}
\hline Reference & Model & $\begin{array}{c}\text { Temperature } \\
\text { (Cooling) }\end{array}$ & $\begin{array}{l}\text { Rainfall } \\
\text { (Drying) }\end{array}$ & Notes \\
\hline Jackson et al., 2015 & HadGEM3 GC2 & $\begin{array}{l}5.0^{\circ} \mathrm{C} \text { growing } \\
\text { season }\end{array}$ & $\begin{array}{l}85 \mathrm{~mm} / \text { growing } \\
\text { season }(21 \%)\end{array}$ & $\begin{array}{l}\text { Model used in this study, } 1980 \text { 's } \mathrm{CO}_{2} \\
\text { levels (difference between AMOC } \\
\text { maintained and collapsed in 2080, see } \\
\text { Extended Data Table 1) }\end{array}$ \\
\hline Drijfhout, 2015 & ECHAM5/MPI-OM & $2-4^{\circ} \mathrm{C}$ & Not provided & $\begin{array}{l}\text { Global atmosphere-ocean general } \\
\text { circulation model, 5member ensemble, } \\
\text { SRES-A1B, } 15 \text { years after onset }\end{array}$ \\
\hline Jacob et al., 2005 & $\begin{array}{l}\text { ECHAM5/MPI-OM \& } \\
\text { REMO }\end{array}$ & $2-3^{\circ} \mathrm{C}$ & $\sim 20 \%$ & $\begin{array}{l}\text { REMO is a regional atmospheric } \\
\text { model, summer values }\end{array}$ \\
\hline Vellinga \& Wood, 2002 & HadCM3 & $2-3^{\circ} \mathrm{C}$ & $\begin{array}{l}\text { 100-150 } \\
\text { mm/growing season }\end{array}$ & $\begin{array}{l}\text { Pre-industrial GHG emissions, } 20-30 \\
\text { years after collapse }\end{array}$ \\
\hline Vellinga \& Wood, 2008 & HadCM3 & $2-5^{\circ} \mathrm{C}$ & $\begin{array}{l}90 \mathrm{~mm} / \text { growing } \\
\text { season }\end{array}$ & IS92a emissions scenario \\
\hline Swingedouw et al., 2009 & IPSL CM4 & $\sim 2^{\circ} \mathrm{C}$ & $\begin{array}{l}90 \mathrm{~mm} / \text { growing } \\
\text { season }\end{array}$ & $\begin{array}{l}\text { Ocean-atmosphere-sea ice-land } \\
\text { coupled GCM, } 5 \text { sets of experiments } \\
\text { over different epochs, largest } \\
\text { weakening - Last Glacial Maximum } \\
\text { (LGM) - 12Sv circulation decline }\end{array}$ \\
\hline
\end{tabular}

Note: The last three entries of the change in rainfall (drying) have been converted (assuming rainfall is evenly distributed throughout the year) to $\mathrm{mm} /$ growing season for consistency.

Extended Data Fig. 5 | Impact of an AMOC collapse on temperature and rainfall across various climate model freshwater hosing experiments. First row, model used in this study. Impact of an AMOC collapse on temperature and rainfall across various climate model freshwater hosing experiments. First row, model used in this study 


\section{Temperature}

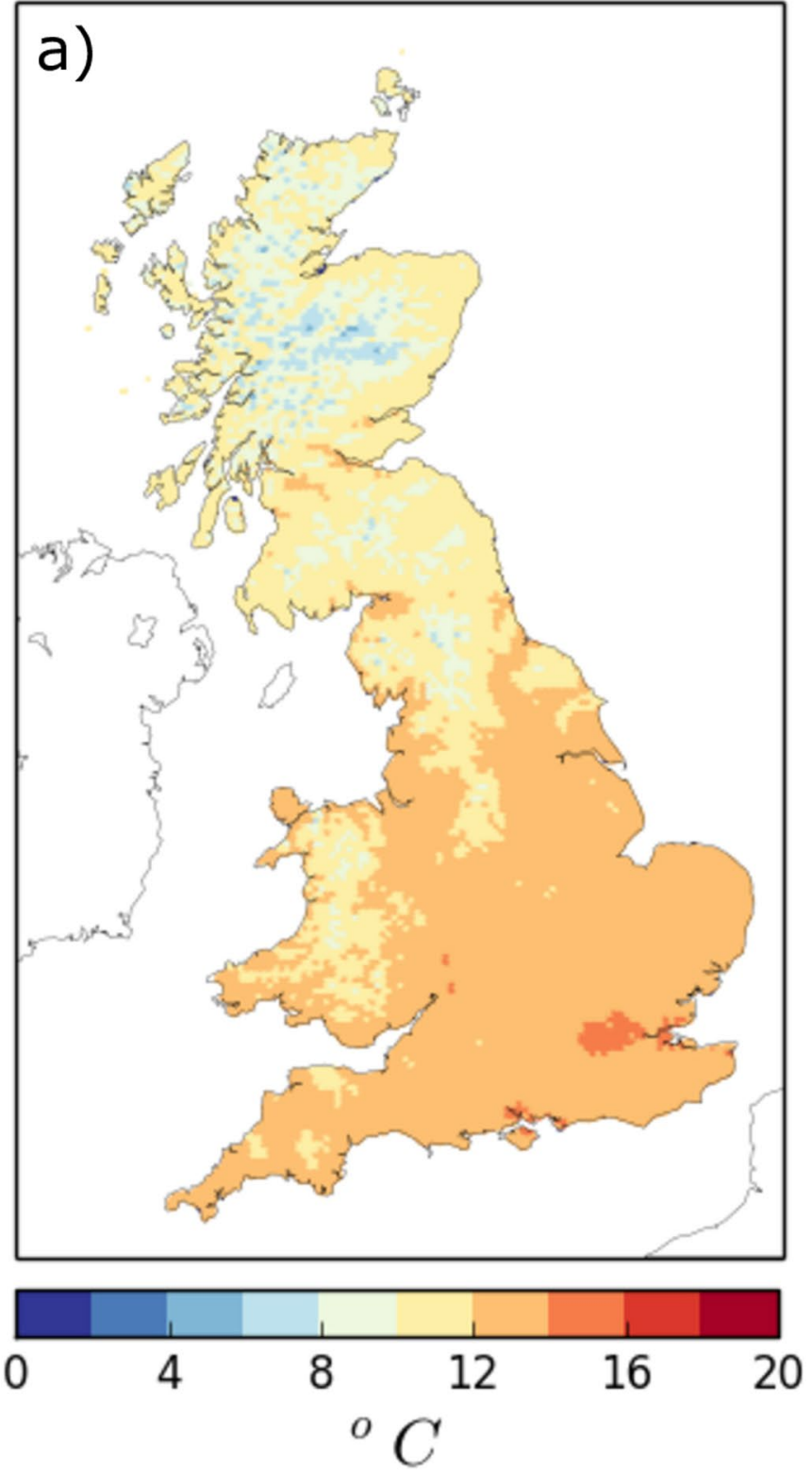

\section{Rainfall}
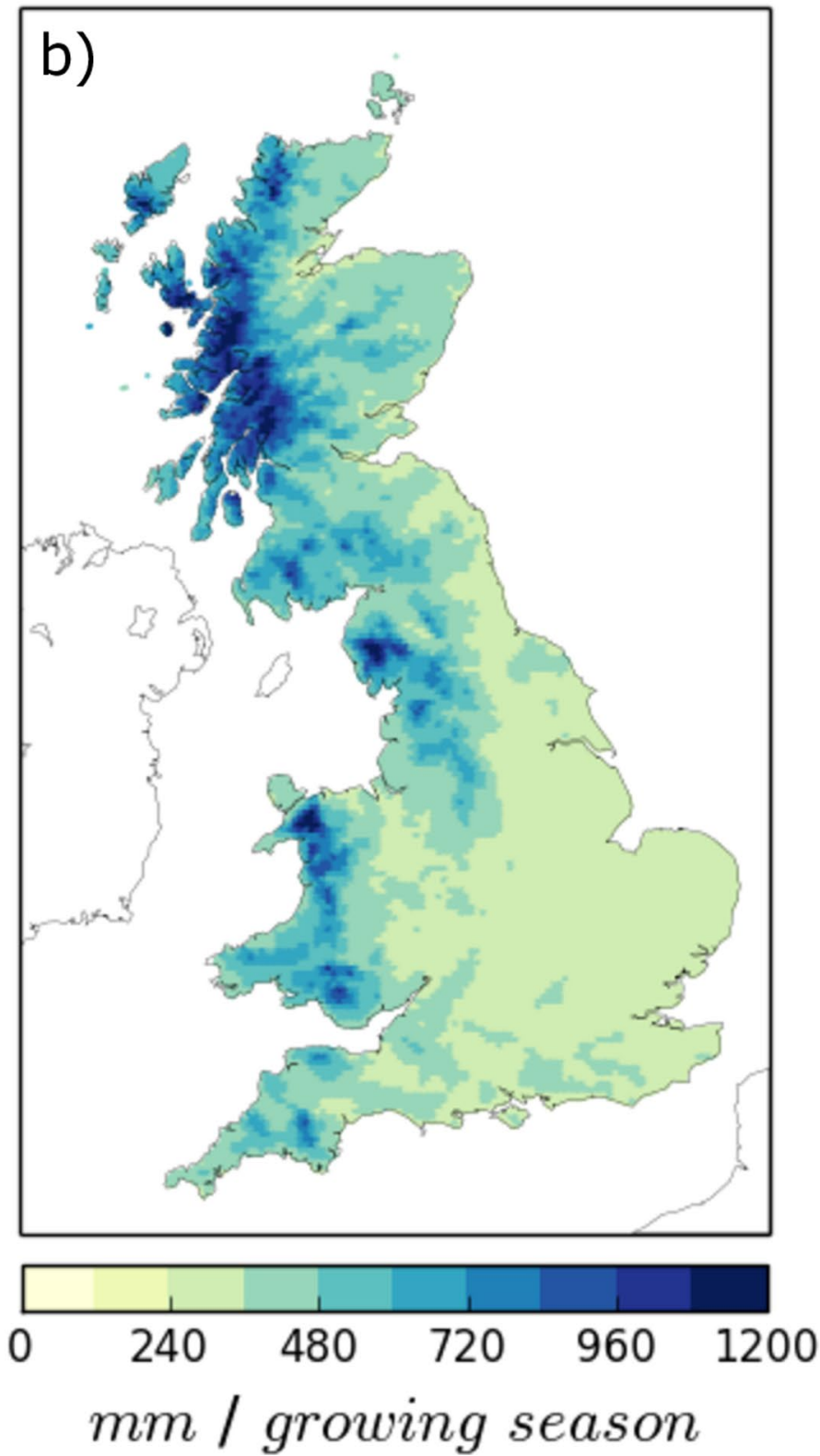

Extended Data Fig. 6 | Surface observations of the mean temperature and total rainfall for the growing season for 1960-1989. a) Mean temperature and b) mean total rainfall for the growing season (April-September) from surface observations for the period 1960-1989 


\begin{tabular}{|c|c|c|c|c|c|}
\hline & Estimate & Std. Error & Z-test & P-value & \\
\hline rain & 0.146 & 0.087 & 1.672 & 0.094 & . \\
\hline rain $>=290$ & -0.313 & 0.128 & -2.442 & 0.015 & $*$ \\
\hline rain $>=300$ & 0.147 & 0.041 & 3.559 & $<2 \mathrm{e}-16$ & $* * *$ \\
\hline rain $>=400$ & 0.009 & 0.001 & 6.754 & $<2 \mathrm{e}-16$ & $* * *$ \\
\hline rain $>=600$ & 0.010 & 0.001 & 9.970 & $<2 \mathrm{e}-16$ & $* * *$ \\
\hline temp & 0.738 & 0.332 & 2.224 & 0.026 & $*$ \\
\hline temp $>=10$ & -0.542 & 0.312 & -1.740 & 0.082 & . \\
\hline temp $>=12$ & -0.243 & 0.128 & -1.898 & 0.058 & . \\
\hline temp $>=13$ & 0.147 & 0.140 & 1.048 & 0.295 & \\
\hline rain*temp & 0.000 & 0.000 & 0.301 & 0.764 & \\
\hline elev & -0.003 & 0.000 & -7.710 & $<2 \mathrm{e}-16$ & $* * *$ \\
\hline slope & -0.060 & 0.011 & -5.546 & $<2 \mathrm{e}-16$ & $* * *$ \\
\hline npark & -0.004 & 0.001 & -2.881 & 0.004 & $* *$ \\
\hline esa & -0.002 & 0.001 & -2.750 & 0.006 & $* *$ \\
\hline greenbelt & -0.002 & 0.001 & -2.947 & 0.003 & $* *$ \\
\hline $\operatorname{dist} 300$ & -0.001 & 0.000 & -3.455 & 0.001 & $* * *$ \\
\hline s_peat & -0.587 & 0.157 & -3.738 & $<2 \mathrm{e}-16$ & $* * *$ \\
\hline s_gravel & -0.613 & 0.125 & -4.883 & $<2 \mathrm{e}-16$ & $* * *$ \\
\hline s_stoney & -0.077 & 0.076 & -1.012 & 0.312 & \\
\hline s_fragipan & -1.278 & 0.173 & -7.376 & $<2 \mathrm{e}-16$ & $* * *$ \\
\hline s_coarse & 0.238 & 0.069 & 3.463 & 0.001 & $* * *$ \\
\hline s_fine & -0.345 & 0.063 & -5.487 & $<2 \mathrm{e}-16$ & $* * *$ \\
\hline constant & -47.352 & 25.079 & -1.888 & 0.059 & . \\
\hline pseudo- $\mathrm{R}^{2}$ & 0.76 & & & & \\
\hline
\end{tabular}

Notes: . *, ** and *** indicate $10 \% 5 \% 1 \%$ and $0.1 \%$ significance levels respectively. Model estimated via QML. $\mathbf{N}=\mathbf{2 2 , 2 2 0}$. The dependent variable is arable land share. The high pseudo- $\mathrm{R}^{2}$ provides an indication of good model fit. Details of variable definitions are presented in the methods section. The model includes a time fixed effect to account for potential time-varying unobserved determinants such as commodity prices. As these are not relevant to the focus of this study, they are omitted from the table but are available from the authors. 

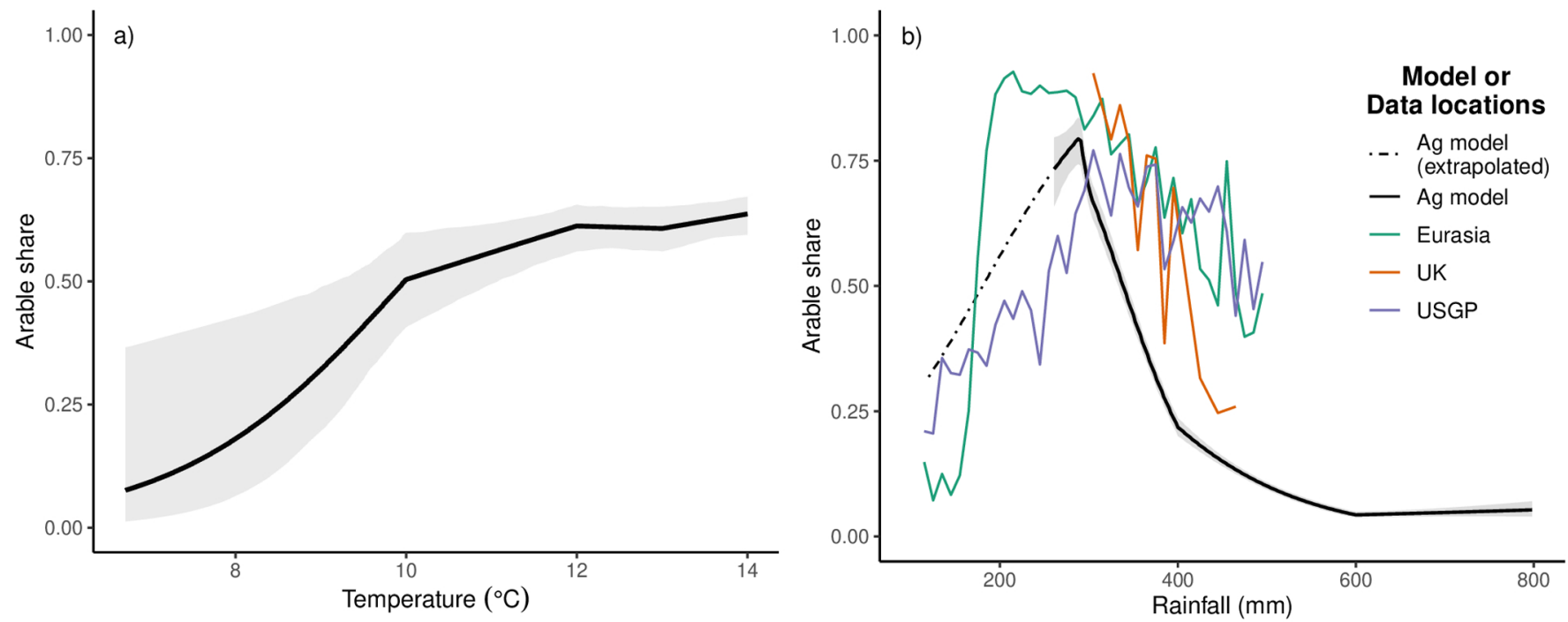

Extended Data Fig. 8 | Estimated impact of temperature and rainfall on arable land share in Great Britain from the agricultural model. Estimated fraction of arable share in Great Britain based on a) temperature and b) rainfall. For b) only: arable shares based on land cover data from Northern Eurasia (Eurasia), United Kingdom (UK), and the US Great Plains (USGP) 
2020

Temperature - Upper quartile

Lower quartile climate

Rainfall - Lower quartile

Mean climate

b)

a)

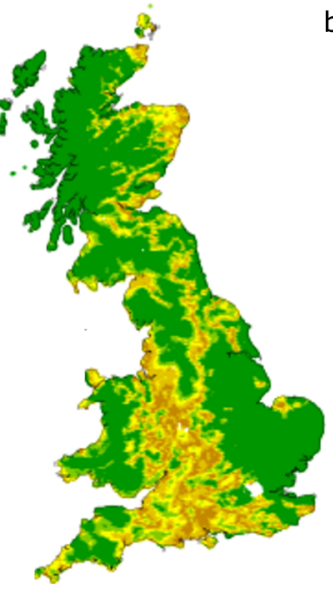

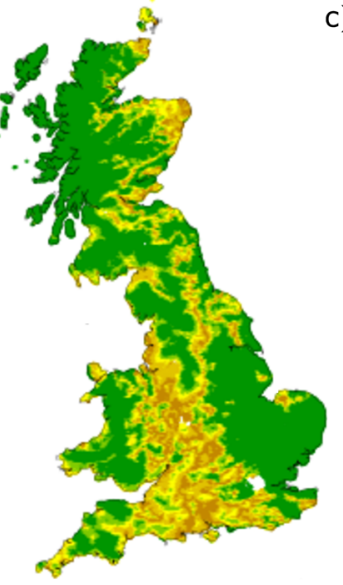

c)

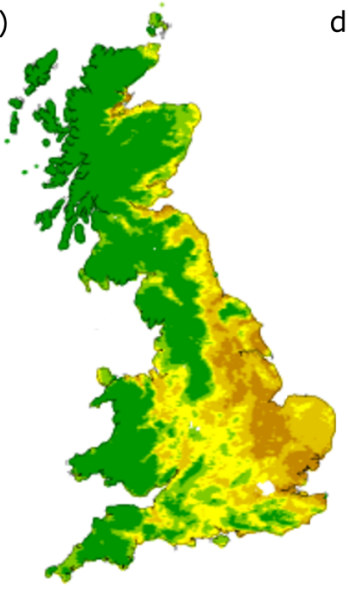

Temperature - Lower quartile

Rainfall - Upper quartile

\section{Upper quartile climate}

)

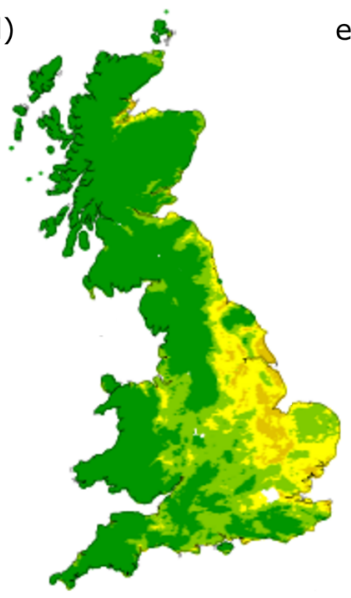

e)

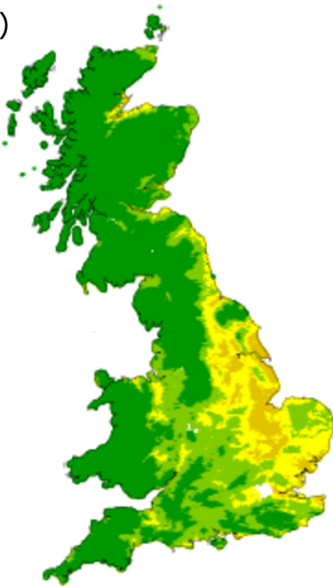

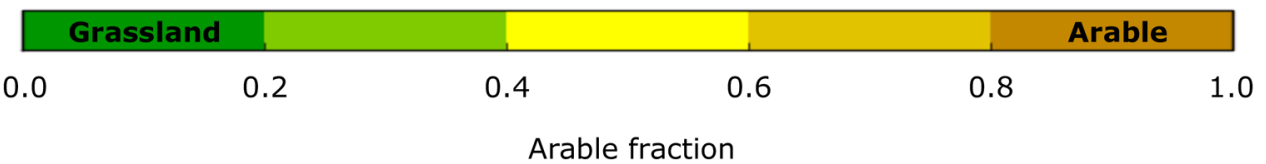

Extended Data Fig. 9 | Impact sensitivity analysis of climate variables has on arable land share for 2020. a) GB map of arable farmland for using the lower quartile temperature and rainfall. b) GB map of arable farmland for using the upper quartile temperature and lower quartile rainfall. c) GB map of arable farmland for using the mean temperature and rainfall. d) GB map of arable farmland for using the lower quartile temperature and upper quartile rainfall. e) GB map of arable farmland for using the upper quartile temperature and rainfall 


\begin{tabular}{|c|c|c|c|c|}
\hline & $\begin{array}{c}\text { Smooth climate } \\
\text { change, no } \\
\text { technological change }\end{array}$ & $\begin{array}{c}\text { Smooth climate } \\
\text { change, with } \\
\text { technological change }\end{array}$ & $\begin{array}{c}\text { Abrupt climate } \\
\text { change, no } \\
\text { technological change }\end{array}$ & $\begin{array}{c}\text { Abrupt climate change, } \\
\text { with technological } \\
\text { change }\end{array}$ \\
\hline AMOC & Maintained & Maintained & Collapse & Collapse \\
\hline Irrigation & No & Yes & No & Yes \\
\hline $\begin{array}{l}\text { Agricultural change value } \\
\text { (£M p.a.) }\end{array}$ & -169 to +48 & -63 to +271 & -393 to -218 & -7 to +139 \\
\hline $\begin{array}{l}\text { Irrigation cost } \\
\text { (£M p.a.) }\end{array}$ & 0 & -1 to -882 & 0 & -527 to -952 \\
\hline $\begin{array}{l}\text { Net value change } \\
\text { (£M p.a.) }\end{array}$ & -169 to +48 & -945 to +270 & -393 to -218 & -959 to -388 \\
\hline
\end{tabular}

Extended Data Fig. 10 | Net impact range on GB agriculture of smooth versus tipping point climate change, with and without ameliorative measures. Net impact range on GB agriculture of smooth versus tipping point (AMOC collapse) climate change, with and without ameliorative measures (technological response) using lower and upper quartile of temperature and rainfall for previous 30-year growing seasons (April-September) 